\title{
EKI hezkuntza proiektu berritzailea eta bere ikasgaikako inplementazioari buruzko azterketa
}

\author{
EKI Innovative Educational Project and the analysis \\ of Its Implementation in each Subject
}

\author{
Andrea Goñi, Jon Altuna* \\ Hezkuntza, Filosofia eta Antropologia Fakultatea
}

UPV/EHU

\begin{abstract}
LABURPENA: Hezkuntza etengabeko berrikuntzan bere funts eta forma birdefinitzen joan da, metodo, teoria eta proiektu berrien bitartez. Egungo gizartearen eskaerari erantzun emanez, EKI proiektu berritzailea konpetentzietan oinarritutako ebaluaziora eta formatu digitalera hurbiltzen da. Artikulu honetarako buruturiko ikerketa lanak ikasgaika EKI proiektuaren metodologiaren inplementazioa eta asebetetze maila ezagutzea du helburu. Horretarako, ikastola bateko Bigarren Hezkuntzako 4. mailako 108 ikaslek eta mintegi ezberdinetako 3 irakaslek hartu zuten parte. Lagina honen ezaugarri bereizgarria Bigarren Hezkuntza osoa EKI proiektuan murgilduta eman dutela da. Ikasleriak Likert motatako galdeketa erantzun zuen eta irakasleriak eztabaida talde batean hartu zuen parte, datu kuantitatiboak eta kualitatiboak bilduz, hurrenez hurren. Maiztasun eta bariantza (ANOVA) analisiak egin ziren emaitzek ezberdintasun estatistikoak esanguratsuak azaleratuz, ikasgai ezberdinen ezarpenean eta EKIk bere proiektuan funtsezkoak hartzen dituen helburuen lorpenean.
\end{abstract}

GAKO-HITZAK: bigarren hezkuntza, hezkuntza proiektua, kasu azterketa, berrikuntza pedagogikoa, ikasketa metodoa.

ABSTRACT: Education is constantly renewing, and it has been redefining its background and way of teaching, with new methods, theories and projects. The EKI project addresses competency assessment and digital format, responding to the demands of current society. This research study aims to analyze the implementation of the methodology of the EKI project in each subject, and its level of acceptance. For this, 108 students of 4th year of secondary education of an ikastola (Basque school) and three of their teachers of different subjects took part. The characteristic of this sample is that this group has completed the whole secondary education immersed in this EKI project. Students answered to a Likert scale questionnaire and the teachers participated in a focus group, gathering quantitative and qualitative data, respectively. Frequency and variance analysis (ANOVA) were carried out. Results showed statistically significant differences in the implementation of the project according to the subjects as well as a partial achievement of the objectives that EKI considers key in its project.

KEYWORDS: secondary school, educational projects, case studies, teaching method innovations, learning methods.

* Harremanetan jartzeko / Corresponding author: Jon Altuna Urdin. UPV/EHU. Hezkuntzaren Teoria eta Historia saila. Hezkuntza, Filosofia eta Antropologia Fakultatea. Tolosa hiribidea, 70. E-20018 - Donostia/San Sebastián - jon.altuna@ehu.eus http://orcid.org/0000-0002-1847-8083

Nola aipatu / How to cite: Goñi, Andrea; Altuna, Jon. (2019). «EKI hezkuntza proiektu berritzailea eta bere ikasgaikako inplementazioari buruzko azterketaw; Tantak, 31(1), 27-51. (https://doi.org/10.1387/tantak.20128).

Jasotze-data: 2018/09/18; Onartze-data: 2018/10/22

ISSN 0214-9753 - elSSN 2444-3581 / (c) 2019 UPV/EHU

(c) (i) Obra hau Creative Commons Atribución 4.0 Internacional-en lizentziapean dago 


\section{SARRERA}

Azkeneko hamarkadetako joan-etorriek islatu bezala, gure egungo hezkuntza-sistemak etengabeko aldaketetan murgilduta jarraitzen du, eta aintzat hartu behar da horrek dakarren guztia. Giza eragile asko ados egongo dira gure hezkuntza-sistema krisi sakonean murgilduta dagoela esaten denean (Esteve, 2003).

Horrekin batera gure hezkuntza sistemak eskaintzen duen ikaskuntza sistema ez da esanguratsua ez eta denboran iraunkorra ere, eta oroimenezko ikasketan oinarritzen da, hainbat esparrutan ikasketa bulimikoa bultzatzearen ideia zabalduta dagoelarik (Llorens, 2013).

Honen aurrean, porrot egin izana lepora dakioke hezkuntza-sistemari? Erabilitako metodologiak ba al du eragin zuzenik? Zer gertatuko litzateke metodologia aldatuko bagenu?

Urteak dira jada EKI proiektua pentsatu, sortu eta hainbat ikastolatan ezarri denetik hona, ikastola askotan lau urte dira proiektua abian jarri zutela.

Proiektu berritzailea ezarri bai, baina urteak pasatu ahala, proiektuari buruzko ebaluazio edo azterketarik egin al da? Emaitzak aztertu al dira? Etorkizuneko belaunaldientzat hezkuntza egokia izaten ari ote da? Eta hau al da jarraitu beharreko metodologia berritzaile bakarra? Irakasgai mota guztientzat da egoki? Nola bizi dute ikasleek proiektua?

Bistan denez, asko dira gaiaren inguruan suerta dakizkigukeen beldurrak, zalantzak eta, agian, ziurtasun faltak. Honenbestez, artikulu honen helburua da irakasgairik irakasgai aztertzea, EKI proiektua DBHn erabiltzen duen ikastola batean, proiektuaren erabilera, asebetetze-maila eta ikasketa-prozesuaren metodologia, eta, ohi den bezala, orain arte egindako ikerketen zenbait ekarpen laburbiltzea. Horretarako inkesta eman zaie ikasleei eta eztabaida-taldea sortu da irakasleekin.

\section{MARKO TEORIKOA}

Gauza jakina da hezkuntza prozesua ulertzea zaila dela, mendeetan zehar izugarrizko aldakuntzak jasan baititu. Aldaketa hauek neurtzeko hainbat adierazle ezberdin topa daitezke, hala nola, belaunaldien arteko aldaketa. Azken hori aintzat hartuta 3 izan dira, historian zehar hezkuntzaren aldaketa nagusiak (Fernández Enguita, 2001): belaunaldiz gaindikoa, belaunaldi artekoa eta, bereziki, belaunaldi barnekoa, gaur egungo gizarteak pairatzen duena, hain zuzen ere. Alegia, belaunaldi beraren barruan aldaketak hauteman daitezke: politika, ekonomia, kultura, familia... Kasu honetan aldaketaren abiadura dela medio, eskolak nahiz familiak irakatsitakoa ez da nahikoa izaten merkaturako bidean. 
Horregatik, kontuan hartu behar da hezkuntza ez dela soilik eskolan edo ikastetxeetan gertatzen den prozesua; izan ere, familian, kalean, lagunartean, telebistan eta Interneten ere garatzen baita.

Hezkuntza psikologiatik begiratuta, teoria hauek ikaskuntza prozesua azaltzen saiatu dira, modurik egokiena bilatuz. Askok filosofia klasiko greziarrean dute oinarri, konduktismoa, kasurako. Egungo hezkuntza paradigmekin bat ez datorren arren, gure gizartean urteetan zehar finkaturik egon den psikologia-korrontea dugu konduktismoa. Baldintzapen bidezko ikaskuntzan du oinarri, barne prozesu mentalei garrantzirik eman gabe. Konduktismoaren barruan irakaskuntza-ikaskuntza prozesua, bideratzen du jakitunak, eta noranzko bakarrekoa da. Edukietan oinarrituta dago, oroimenezko ikaskuntza eta errepikapena bultzatuz. Teoria hau gure eskoletan 70eko hamarkadara arte erabilitakoa izan da (Santana, 2007).

Konduktismoak jartzen du arreta behatu eta neur daitezkeen portaera edo jarreretan. Gure buruan estimulu ezberdinei ematen zaizkien erantzunak modu kuantitatibo batean beha daitezkeela uste du, eta barne prozesu mentalak gertatzearen aukera guztiak baztertzen ditu. Teoria honen garapenean eragina izan duten pertsona garrantzitsuenetarikoen artean Pavlov, Watson, Thorndike eta Skinner daude (Mergel, 1998). Konduktismo tradizionalen helburua portaeren lege orokorrak identifikatzea izan da.

70eko hamarkadan berriz, psikologo ikerlariek arreta jarri dute giza ikaskuntza prozesuan kognizioak jokatzen duen paperean. Modu honetan, erredukzionismo konduktistak prozesu kognitibo kausalei uzten die lekua, subjektu pasiboa informazioaren prozesatzaile aktiboa bihurtuz (Santana, 2007).

Teoria kognitibistak informazioaren trataera hiru fase ezberdinetan egiten du; lehenengo fasean, zentzumenen erregistroen bitartez sartzen da. Ondoren, epe laburreko memorian prozesatzen da eta, azkenik, epe luzeko memoriara transferitzen da, biltegiratu eta, gerora, berreskuratu ahal izateko. Jasotzen dugun informazioaren gehiena ez da sekula epe laburreko memoriara pasatzen, normalean segundo batzuen ostean desagertzen baita. Teoria honen bultzatzailerik ezagunena Jean Piaget dugu (Mergel, 1998). Kognitiboek ez dituzte lege orokorrak bilatzen, ezberdintasun indibidualaren arrazoiak eta zergatiak baizik.

Irakaskuntza-ikaskuntza komunitatearen barruan, kognitibismoari egindako kritikak ugariak izan dira: talde handietan aurrezagutzak bereiztea eta jarraitzea zaila dela, ideiak, motibazioak, kontzeptuak... ezberdinak badira, dena nahasteko arriskua dutela, ikasleak ez duela parte hartze aktiborik...

XX. mendearen amaieran hainbat ikerlari bi teoria hauen artean kokatzen dira ikuspegi berriak sortuz. Era honetan konstruktibismoa sortzen da. Konstruktibismoan, ikasleak bere errealitatea eraikitzen du, bere esperientziatik eratorritako hautematearen arabera interpretatzen du. Gauzak horrela, ikaslearen ezagutza bizitzako esperientzien eta sinesmenen araberakoa da (Mergel, 1998). 
Teoria honen barruan, ikasleak ez du hartzaile hutsaren papera hartzen, iristen zaion informazioaren esanahia eraikitzen ahalegintzen da. Ezer $e x$ novo eraikitzea eskatzen du ikaskuntzak, horretarako informazioa berreskuratzeaz gain motibazioa ere eduki behar du ikasleak, hots, nahi izan behar du. Azkenik, ikuspegi sozialari erreparatuz, eskuratze-eraikitze hori gizarte-testuinguruak ahalbidetzen du (Gil, 2013). Testuinguru honetan koka dezakegu EKI proiektuaren teoria pedagogikoa, integrazioaren pedagogia deiturikoa.

Ildo beretik, egungo egoera kontuan hartuz, teoria berri bati buruz hitz egin daiteke, konektibismoaz, hain zuzen. Azkeneko 20 urteetan, teknologiak berrantolatu egin du komunikatzeko, bizitzeko eta ikasteko dugun modua. Ikaskuntza beharrak eta ikaskuntza prozesuak deskribatzen dituzten printzipioek egungo gizartearen errealitatea izan behar dute oinarri (Siemens, 2004).

Hezkuntza-sistemaren ikuspuntua aldatu ahal izateko ezinbestekoa suertatzen da irakaskuntza-ikaskuntza prozesuaren oinarria abiapuntutzat hartzea, aurrerantzean metodologia berriei atea irekitzeko; adibidez, konpetentzietan oinarritutako metodologiari (Gimeno Sacristán, 2008).

Konpetentzietan oinarritutako diskurtsoa eremua irabazten joan da hezkuntza formalaren esparru guztietan, goi mailako hezkuntzatik hasita haur hezkuntzaraino, hainbat herrialdetan ikuspegi estrukturala bilakatuz. Administrazio askok aplikatu izanak diskurtso hori hedatzen lagundu du (Coll, 2007) eta honen adibiderik gorena da Euskal Autonomia Erkidegoan indarrean dagoen abenduaren 22ko 236/2015 dekretua. Heziberri 2020 planean, hain zuzen ere, aurki daiteke konpetentzien isla.

Hezkuntza da berez, a priori, «berritzaileak» diren kontzeptuak edo teoriak sarri ageri diren eta hedatzen ikusten dituen esparrua. Kontzeptu edo teoria berritzaile hauek normalean irtenbidea ematen diote hezkuntza-sistemak dituen arazo eta gabezia guztiei eta onarpen gradu altua lor dezakete denbora epe laburrean. Indarraldia ere laburra izaten da, berriz, berehala etortzen baitira berritzaileagoak direnak eta arazoei irtenbide egokiagoak ematen dizkieten teoria berriak. Batzuetan, hezkuntza pentsamenduaren eta ideien historiak etengabeko birformulazio prozesua ematen du, ideien eta pentsamenduen garapen prozesu aberasgarria, alegia (Coll, 2007)

Aurrekari hauek kontuan izanda, geure buruari galdetu beharko genioke ea konpetentzietan oinarritutako hezkuntza ez ote den beste hezkuntza katemaila bat planteamendu berritzaile hauen guztien artean. Bestalde, esan daiteke konpetentzietan oinarritutako hezkuntzak historikoki planteatutako arazoei beste irtenbide batzuk ematen dizkiola. Hortaz, kasu-azterketa honen helburua da eztabaida hauek aztertzea EKI proiektua lau urte ezarrita daramatzan ikastola batean.

Cepeda-k (2004) adierazten duen moduan, konpetentzietan oinarritutako hezkuntza uler daiteke ikasleari egiten zaion jarraipen prozesu gisa, ikasleak bereganatu dituen gaitasunak eta egindako aurrerapenak neurtzeko. Prozesuaren jarraipen honek prozesu osoan zehar informazioa be- 
rreskuratu ahal izatea ahalbidetzen du, beharrezkoak diren moldaketei aukera emanez jasotako informazioari esker.

Beraz, ezin uka daiteke hezkuntza mota hau nahikoa berria dela. Honenbestez, konpetentzietan oinarritutako hezkuntza probarako tartean aurkitzen da, eta konpetentzia terminoa eta proposamen pedagogiko eta didaktiko hauek, indar handiarekin sartu dira azkeneko hamarkadetan gure hezkuntza-sisteman (Coll, 2007).

\section{HEZKUNTZA BERRITZAILEAREN BILA: EKI PROIEKTUA, ETENGABEKO BERRIKUNTZA?}

Testuinguru honetan koka dezakegu EKI proiektuaren teoria pedagogikoa, integrazioaren pedagogia deiturikoa. EKI proiektua konpetentzietan oinarritutako hezkuntza eredu bat da eta konpetentzia digitala arlo guztietan integratzeko aukera ematen du (Gereka, Odriozola, Arregi eta Vera, 2017).

Zabalak (2015) EKIren inguruan Mikele Aldasorori, Euskal Curriculumaren garapenean eta EKI proiektuan partaide izandakoari, egindako elkarrizketan adierazten den bezala, oinarrizko konpetentzien araberako hezkuntza-ereduaren hirugarren zehaztapen maila da eta EKIren egitasmoa bide horretan gauzatutako material didaktikoa ere izango litzateke. Proiektu honetan Ikaselkar argitaletxeak eta Ikastolen Elkarteak elkarlanean sortutako materiala izanik (Lizarralde, 2016).

Hau horrela izanda, aurreikusitako testuinguruan, EKI proiektuaren emaitzak zehaztasunez ezagutzea beharrezkoa suertatzen da. Horretarako, ezinbestekoa da bilakaera, kontrola eta jarraipena ahalbidetzen duten tresnak aurreikustea.

Ikastolen Elkarteak sorturiko EKIk Ostadar ekimenean errotzen ditu bere sustraiak. Azken honek ikasgai instrumentalak (hizkuntzak) zein zientzietarako (Natur eta gizarte zientziak) material iraultzailea jarri zuen mahai gainean. Berorietako bakoitzean lau unitate proposatzen ziren, zeintzuetatik irakasleak berak hiru hautatzen zituen, Ikastolen Elkartearen gomendioari jarraikiz, ikasturtean zehar irakasteko.

Ostadar egitasmoak ekarri zuen, euskaraz bederen, konpetentzietan oinarritutako lehen ikasmateriala. Bertan indar berezia jartzen da konpetentzia bitarteko ikasketetan.

Ikergaiari erreparatuz, EKI material didaktiko berritzailea da. EKI proiektuak Euskal Curriculumaren garapenerako ikasmaterialak sortu, ekoitzi eta eskaintzen ditu, hori guztia, jakina, konpetentzietan oinarrituta eta integrazioaren pedagogiaz baliatuz (Amezua, 2014).

Konpetentziei dagokienez, ikaslearen irteera profila du abiapuntu eta helmuga. EKIren arabera bizitzaren edozein egoeratan gai izatea lortu behar du ikasleak. Horrexegatik, EKIren materialek lau osagai nagusi dituzte (Ikaselkar, 2014): 
Ardatza: konpetentziak landuz ikasi eta irakasten da.

Edukiak: euskal kultura-ibilbidean eta curriculum ofizialetan oinarritzen dira.

Tresnak: ikas-arlo guztietan prozedura sistematizatuak errazten dira ikasten eta egiten jakiteko.

Eleaniztasuna: euskara ardatz duen hizkuntza-planteamendu integratua egin da.

Bestalde, integrazioaren pedagogiari dagokionez honako hau planteatzen du EKI proiektuak: «Egoerei irtenbideak aurkitzen ikastea, egoera berrietan ikasitakoa baliatzeko». Egoera erreal baten aurrean, ikasleak egoera horretan behar dituen baliabideak bilatzen eta erabiltzen ohitu behar du; bakarrik nahiz talde-lanean, irtenbideak aurkitzen saiatu behar du, eta ikasi duena egoera berrietan baliatu (ikaselkar.eus).

Testuinguru honetan 9 ezaugarri bereizgarri ditu proiektuak. Haien artean konpetentzia digitala, ikasketa kooperatiboa eta konpetentzietan oinarritutako hezkuntza dira aipagarrienak.

EKI proiektua 6 ezagutzatarako izan zen sortua, Ostadar ikasmaterialaren ezagutza berdinetarako hain zuzen ere: Ingelesa, Euskara, Gaztelera, Gizarte zientziak, Matematikak eta Natur zientziak. Bakoitzaren barruan hiru unitate didaktiko lantzen dira kurtso bakoitzeko eta bakoitzak segidako lau fase ditu, lortu nahi diren helburuak betetzeko, eta ebaluaziorako baliabide propioak eskaintzeko.

Bestalde, euskarriari dagokionez EKIk eredu mistoa konbinatzen du, hots, papera eta digitala batera. Ikaselkar argitaletxeak, edizio-euskarrien konbinazioa landu du EKI proiektuan hasieratik, papera eta digitala batera zortzi ikas-arloetan.

Beraz, EKI deitzen den material honek guztiak 2013 urteko udaberrian ikusi zuen argia. Azkeneko urte hauetan, hainbat aldaketa eta hobekuntza sortu eta editatu egin dira. Amezuak (2014) baieztatzen du Natur zientzietako irakasgaian bigarren hezkuntzako bigarren mailan EKI programaren bidez konpetentziak hobeto lortzen laguntzen duela beste metodologia tradizionalek baino. Hala eta guztiz ere, 4 ikasturtez indarrean egon eta gero, ez da EKI proiektu osoaren eta irakasgai guztien inongo ikerketa sakonik egin.

Hau harrigarria suerta liteke, azken finean, EKI baita, hezkuntza-sistema berritu nahian, euskal hezkuntzak XXI. menderako egin duen apustu irmo eta ausarta.

\section{HELBURUAK}

Artikulu honen atzean den ikerketa-lanaren helburua izan da irakasgaien arabera aztertzea EKIren erabilera, asebetetze-maila eta ikasketa prozesuaren metodologia, proiektu hori DBHn ezarrita duen ikastola baten. 


\section{BERARIAZKO HELBURUAK}

B.H.1: EKI proiektuaren ikasketa prozesuaren metodologia irakasgaiaren arabera zein puntutaraino betetzen den aztertzea.

B.H.2: EKI proiektuaren erabilera aztertzea ikasgai ezberdinen arabera; Gizarte Zientziak, Natur Zientziak (Fisika-Kimika/Biologia-Geologia), Matematika, Ingelesa, Euskara eta Gaztelera (Lengua Castellana y Literatura).

B.H.3: EKI proiektuaren asebetetze-maila ezagutzea ikasgaien arabera; Gizarte zientziak, Natur zientziak (Fisika-Kimika/Biologia-Geologia), Matematika, Ingelesa, Euskara eta Gaztelera (Lengua Castellana y Literatura), bai irakasleen eta bai ikasleen artean ere.

\section{METODOLOGIA}

Hau lortzeko nahian egokia da kasu azterketaren metodologia erabiltzea, zentro honen errealitatea sakonki aztertzeko. Ikerketa mota honek, ordea, izan badu mugarik, ezin baitira emaitzak beste testuinguruetan ez aplikatu ez eta orokortu ere.

Hori dela kausa, ikerketa honen helburua da testuinguru batean kokatutako errealitatea aztertzea eta deskribatzea, ikerketa esperimentala nahi izan gabe, zeinean esku-hartze baten ondorioz hobekuntzak kuantifikatu nahiko liratekeen, aldaketak aurrera eramateko nahian (Altuna, 2010).

Honenbestez, Dendaluzeren (2008) sailkapenean oinarrituz, ikerketaren izaera enpirikoa da, ikerketa-arazoei erantzuna ematea bilatzen baitu errealitatetik datuak eskuratuz. Orobat, ikerketa hau deskribatzailea ere bada, ikertzen ari den fenomenoaren aldagaiak (frekuentziak, ehunekoak, batezbestekoak...) deskribatzea bilatzen baitu. Gainera, datuak biltzeko tresnei erreparatuz ikerketa mistoaz hitz egin daiteke, non datu kualitatiboak eta kuantitatiboak jasotzen diren. Kuantitatiboa, kuantifikagarriak diren fenomenoak ikertzen dituelako eta froga estatistikoak erabiltzen dituelako datuen analisian, eta kualitatiboa, fenomenoak ikertzen baititu datu eta analisi kualitatiboak erabiliz.

Beraz, ikerketa honetarako kasu azterketa aukera onena dela aintzat hartuz, hainbat autoreren aburuz definituko da kasu azterketa kontzeptua. Yin-en arabera (2003) kasu azterketa bat, errealitateko testuinguru baten barruan, fenomeno garaikide bat ikertzen duen ikerketa enpirikoa da, bereziki, fenomenoaren eta testuinguruaren arteko mugak oso argiak ez direnean (Altuna, 2010).

Horren haritik, Stake-k (1998) honako hau gehitzen du: kasu azterketa batean, kasu partikularraren konplexutasuna zehaztea espero da. Kasua azter dadin bere baitako interesik dagoenean egingo delarik. Hortaz, kasu konkretu baten konplexutasuna eta bereizgarritasuna aztertzea du helburu (Altuna, 2010).

Kasu-azterketa ez da mugatzen errealitateari buruzko informazioa ematera, kontuan hartzen baititu errealitate hori osatzen duten arazoak, paradoxak, gatazka-egoerak eta egiazko gertaerak (Bujan, 2001), beraz, ezin hobea suertatzen da kasu konkretu honetarako. 


\section{POPULAZIOA ETA LAGINA}

Ikerketaren aztergai den elementuari hertsiki begiratuz, EKI proiektua bada ere, informazioa lortzeko bitartekari beharrezkoak dira eskola honetako irakasleria eta, bereziki, ikasleria. Beraz, horiexek osatzen dute estatistikan 'populazio' esaten zaiona.

Eskola zehatz baten kasua izanik, posiblea izan da 2017-18 ikasturterako populazioaren zerrendak lortzea, hori oinarritzat hartuz, laginketa bat burutzeko. Institutuak emandako informazioaren arabera:

- Zuzendaritza taldea 7 pertsonak osatzen dute: zuzendaria, HHLHko zuzendaria eta bi koordinatzaile, DBH-Batxilergoko zuzendaria eta bi koordinatzaile.

- Bigarren hezkuntzako irakasleria 44 pertsonak osatzen dute.

- Ikasleria 470 ikaslek osatzen dute DBHn, DBHko maila bakoitzeko 4 talde.

Datu hauetatik abiatuz, ikasleen kasuan, laginketa estratifikatua egin da. Laginketa mota honetan populazioa multzotan banatu eta ondoren, multzo bakoitzaren barnean, zorizko laginketa bat egiten da (Juaristi, 2003). Kasu honetarako lagina DBHko 4. mailako ikasle guztiak izan dira, 118 ikasle hain zuzen ere.

Multzokatzeko garaian, kontuan hartu beharreko lehen ezaugarria irakasgaia izan da. Eskola osoaren adierazgarri den lagina lortzeko, zoriz, DBHko 4. mailako ikasleak sei taldetan banatu dira ikasgaien arabera. Talde bakoitzeko ikasle kopurua nahiko berdintsua izanik (15-20), ez da arazorik ikusten adierazgarritasunarekin.

1. taula

Ikasleen lagina

\begin{tabular}{|c|l|l|l|}
\hline \multicolumn{1}{|c|}{ Tresna } & \multicolumn{1}{|c|}{ Ikasgaia } & \multicolumn{1}{c|}{$\begin{array}{c}\text { Ikasle lagina } \\
\text { ikasgaika }\end{array}$} & $\begin{array}{c}\text { Behin-betiko } \\
\text { partehartzaileak }\end{array}$ \\
\hline Galdetegia & Euskara & 20 & 12 \\
\hline Galdetegia & Natur zientziak & 20 & 18 \\
\hline Galdetegia & Gizarte zientziak & 21 & 21 \\
\hline Galdetegia & Ingelesa & 19 & 19 \\
\hline Galdetegia & Lengua Castellana & 20 & 20 \\
\hline Galdetegia & Matematika & 18 & 18 \\
\hline Osotara & 118 & 108 \\
\hline
\end{tabular}




\section{DATUAK BILTZEKO TRESNAK ETA TEKNIKA}

Ezer baino lehen, ikerketa aurrera eramateko tresna eta teknika bat baino gehiago erabili dela aipatu behar da. Izan ere, proposatutako ikerketa-arazoa hobeto argitzen du teknika-konbinazioak.

\section{Datu kuantitatiboak: ikasleentzako galdetegia}

Ikerketa honetan inkesta galdeketa hautatu da datu kuantitatiboak biltzearren. Inkestaren galderak prestatzerako orduan berorren helburuak eta gaiari buruzko teoriak hartu dira kontuan. Oro har, galdetegia galdera zehatz eta orokorrez osatuta dago. Erabilitako inkesta motari dagokionez, deskribatzailea da galdera-sorta, zeinean aztertzen diren teoria bakoitza osatu ahal izateko ezinbestekoak izan daitezkeen aldagaiak. Inkestan lortutako emaitzekin populazioaren deskribapenak egin ahal izan dira, inferentzia kausalik gabekoak, jakina (Juaristi, 2003).

Hau horrela izanda, EKI proiektuaren ezaugarri bereizgarriak hartu dira aldagai, aukeratutako eta kasuan kasuko ezaugarriak zein puntutaraino agertzen diren aztertu ahal izateko.

Inkestak galdetegia du oinarri, zeina behin eman zaien DBHko 4. mailako 108 ikasleri. Horretarako, Etika ikasgaiko saioa hautatu da lau klase ezberdinetan inkesta egin ahal izateko, hauxe baita ikasgai bakarra - Gorputz Hezkuntzaz gainera - gela naturaleko ikasleriak elkarrekin jasotzen dituena, gainerakoetan ibilbidearen araberako aukerako ikasgaietan eta geletan baitira (letrak, zientziak, ibilbide teknologikoa, frantsesa, SSLIC, Gizarte, Hizkuntza Taldea...).

Galdetegi honetan neurtu nahi ziren aldagaiak ezin ziren galdera bakarrekin neurtu, dimentsio ugari dituen fenomeno konplexuak neurtu behar baititu. Galdera bakar batekin aztertu behar diren fenomeno konplexu hauek neurtzeko, bereziki erabilgarriak dira indizeak eta eskalak; hau da, fenomenoak zeharka neurtzeko tresnak. Halako indize eta eskalek, fenomenoaren dimentsio bati zenbakizko balioak egokitzen baitizkiote, atributu izeneko berezitasun kualitatiboak aldagai deritzen serie kuantitatibo bihurtuz (Juaristi, 2003). Beraz, jarrerak eta iritziak neurtzeko eskalen artean ezezagunetarikoa Likert eskala denez, berau izan da, hain zuzen ere, ikerketa honetan erabilitako eskala. Hortaz, 1-5 bitartean, batez besteko puntuazio batekin baloratu da item bakoitza, eta honako balio hauek esleitu zaizkie: 1-2 artean erabateko desadostasuna; 2-3 artean desadostasuna; 3-4 artean adostasuna, eta 4-5 artean erabateko adostasuna. Hau horrela izanda ere, galdera ireki bakarra txertatu da, ikasleen iritzia sakontasun gehiagorekin ezagutu nahian.

Honako hauek dira aztertutako 3 dimentsioetako bakoitzean erabilitako itemak: 


\section{Galdetegian erabilitako itemak}

@Ikasketa_prozesua

Unitate didaktikoaren hasieran egoera problematiko/arazo egoera/hasierako-egoera bat planteatzen da.

Egoera horri aurre egiteko, baliabideak nik bilatzen eta erabiltzen ditut.

Edukiak ariketa eta jardueren bitartez nik eskuratzen ditut.

Edukiak irakasleak zuzenean ematen ditu, apunteak edo testu liburuen bidez.

Animazioak eta simulazioak maiz erabiltzen ditugu.

Ariketa edo jarduera bat bidaltzen didatenean, normalean ariketa egiteko behar dudan informazioa guztia apunteetan edo liburuan egoten da.

@EKI_klasean

Beti/ia beti gure ikasmateriala klasean hartutako apunteak eta irakasleak banatutako fitxak edo apunteak dira.

Gure ikasmateriala, konbinazioa da. Bai papera (liburuak...) eta bai oinarri digitala (ordenagailua...) erabiltzen dugu maiz.

Gehienetan Ekigunean egiten dugu lan.

Normalean, lan koadernoetan eta jarduera-fitxetan egiten dugu lan.

Hainbat baliabide digital askotan erabili ohi ditugu; drive, geogebra, google sites, Lucidchart,......

\section{@ Asebetetzea}

Nola sentitzen zara ebaluazio erarekin?

Nola sentitzen zara EKIrekin lan egiten?

Zerbait aldatuko zenuke? Baiezkoa bada azaldu labur.

Dagokizuen ikasgaia ikasteko era eraginkorra iruditzen zait eta oso eroso sentitzen naiz

Ikasketa prozesua kuantifikatzeko bertan dauden 6 itemak aldagai bat osatuz bildu dira. Kasu honetan, EKI integrazioaren pedagogian oinarritzen da eta EKI proiektuaren oinarrietan ikus daitekeen moduan egoera erreal baten aurrean, ikasleak egoera horretarako behar dituen baliabideak bilatzen eta erabiltzen ohitu behar du; bakarka nahiz talde-lanean, irtenbideak aurkitzen saiatu behar du, eta ikasi duena egoera berrietan aplikatu. Ezaugarri hauek oinarritzat hartuz galdetegiko itemak sortu dira (Ikaselkar, 2014) aztertu ahal izateko dimentsio hau gertatzen den edo ez. Hau horrela izanda eta aldagaia 6 itemez osatuta egonik, 1-5 bitarteko balio banarekin, 30 puntuko puntuazioa da lor zitekeen altuena.

EKI_Klasean deituriko dimentsioak 5 item ditu eta EKIren erabilera ikasgelan zenbaterainokoa den neurtzen du. Beste ezaugarrietan bezala, di- 
mentsio hau kuantifikatzeko nahian ikasketa prozesuaren aldagaia sortu da. 5 itemez osatutako aldagaia izanik, dimentsio honetan lor zitekeen puntuaziorik altuena 25 puntukoa da.

Azkenik, EKIri buruzko iritzia eta asebetetze maila eskatu zaio ikasleriari, eta horretarako 4 galdera egin zitzaizkien (2. taula). Berorietatik hiruk Likert eskala erabiltzen zuten (1-5 bitartean) eta azken aurrekoa galdera irekia zen. Emaitzen analisia atalean, lehen hiru galderak aztertuko dira batera, batezbestekoak konparatuz. Oraingo honetan ere, ikasgaika konparatu nahi izan da eta, bi aldagaiok kategorikoak izanik, batezbestekoen konparaketa egitea hautatu da.

Bestalde, estatistikan, Cronbachen alpha, $\alpha$ alpha hizki grekoaz irudikatzen dena, test edo azterketa baten fidagarritasuna edo barne trinkotasuna neurtzen duen adierazlea da, hots, test bateko galderek ezaugarri bat, neurketa zuzena onartzen ez duena, zenbaterainoko zehaztasunez neurtzen duten aztertzen du Alfa de Cronbachen testak. Egindako inkestan Alfa de Cronbach .715koa da eta galderen arteko barne trinkotasun ona dagoela aipatzen digu. Izan ere, Norman eta Streiner-en aburuz (1996), koefizientea 0.70 etik gorakoa izateak fidagarritasun altukoa dela adierazten du.

\section{Datu kualitatiboak: irakasleen eztabaida taldea}

Datuak biltzeko orduan, ikerketa mistoa den aldetik, datu kualitatiboak ere bildu ditu ikerketa honek. Oraingo honetan, eztabaida-taldearen teknika erabiliz.

\section{Irakasleen eztabaida-taldea}

Irakasleriaren iritzia ere jasotzea ezinbestekoa suertatzen zenez, eztabaida taldea erabili zen helburu hori betetzeko asmoz.

Hiru pertsonak osaturiko eztabaida-taldea izan zen: Gizarte Zientzietako irakasle bat, Natur zientzietako beste irakasle bat eta 2. Hezkuntzako eta Batxilergoko zuzendaria, aldi berean hizkuntza-irakasle ere badena. Hirurek ezagutzen dute DBH eta EKI bertan baitira tutore. Eztabaidaren helburu nagusia haiek gaiari buruz duten pertzepzioa ezagutzeaz gain, haiek ikusten dituzten aldagaiak aztertzea zen.

Kategoriak zehatz-mehatz definitu ziren galdetegian erabili ziren dimentsio ezberdinak kontuan izanda eta kategoria hauetan oinarrituz honako gidoi hau aurkeztu zen eztabaida zuzentzeko asmoz:

$\rightarrow$ Konpetentzia digitala

$\rightarrow$ Ebaluazioa

$\rightarrow$ Irakaskuntza metodologia

$\rightarrow$ EKIren erabilera

$\rightarrow$ EKIren asebetetze maila irakaslariaren artean. 
Halere, kontuan izan behar da eztabaida taldean galdera irekiak aurkeztu zirela, orobat, eztabaidak hartzen duen norabidearen arabera gai batzuk sartu ziren, beste batzuen garrantzia murriztuz.

\section{DATUAK AZTERTZEKO TRESNAK}

Bildutako datu kuantitatiboak, Google galdeketaren bitartez jaso ziren, eta kodifikatu eta analizatu ziren IBM SPSS Statistic 24 (Statistical Padckage for Social Sciences) programa informatikoaren bitartez. Galdera eta item bakoitzari zegokion zenbakizko datua eta atal bakoitzean birkodifikatu beharreko aldagaiak programaren barruan birkodifikatu ziren.

Programa informatikoaz baliatuz hainbat analisi ezberdin eraman ziren aurrera, kasurako: Faktore bakarreko ANOVA, Frekuentzien analisia, Pearson Korrelazioa, Medien konparaketa, ETA-karratua.

Esan bezala, efektuaren tamaina neurtzeko ETA-karratua erabili da eta Cohen and Miles eta Shevlin (2001) autoreen aburuz, hiru motatakoa izan daiteke lotura edo harremana ateratako koefizientearen arabera: 0.01-lotura txikia, 0.06-lotura ertaina eta 0.14 tik gorakoa lotura sendoa.

Esan bezala, item bakoitzak 1-5 bitarteko balioa hartzen zuen. Item hauek dimentsio ezberdinen arabera multzokatuta, aldagaiak sortuz, egiaztatu haietariko bakoitza bere zenbakizko tartearen barruan eta ikasgaiaren araberako ezaugarri ote zen.

Datu kualitatiboei erreparatuz, irakasleen eztabaidari dagokionez, esan beharra dago ordubete eta hiru minutuko iraupena izan zuela eztabaidak eta ikerketa burututako zentroan egin zela maiatzaren 17an. Bestalde, grabagailua erabili zen ondoren transkribatu ahal izateko. Honen helburu nagusia da, behin informazioa bilduta, behin eta berriz irakurri edo entzun ahal izatea azterketa egiteko bildutako informazioaren azterketa egiteko nahian eta, kategorizazio erabiliz, datuen azterketa eta sintesia egin ahal izateko.

Behin grabaketa eginda, parte-hartzaileak kodifikatu egin ziren hurrengo taulan ageri den kodea erabiliz:

\begin{tabular}{l|c}
\multicolumn{2}{c}{ 3. taula } \\
Eztabaida taldearen partehartzaileen kodifikazioa \\
\hline \multicolumn{1}{c|}{ IRAKASLEA } & KODEA \\
\hline Natuz Zientzia & $\mathrm{NT}$ \\
Gizarte Zientzia & $\mathrm{GZ}$ \\
Hizkuntza & $\mathrm{HZ}$ \\
\hline
\end{tabular}

Ondoren esandakoak ordenatu eta aztertu ziren, garrantzitsuak ziren gaiak eta arloak ondo ezagutu ondoren parte-hartzaileak zertan zeuden 
ados eta zertan ez aztertzeko; kontsentsua eta desadostasuna ezagutzea eta interpretatzea baita, hain zuzen ere, eztabaida taldearen potentzialtasuna.

Ikerketaren objektibotasuna mantentzeko nahian, aurretik aipatu bezalaxe, eztabaida-taldearekin kategorizazio teknika erabili zen, ikerlariaren subjektibotasunak ahalik eta eragin txikiena izan zezan.

\section{IKERKETAREN MUGAK}

Ezin aitortu gabe utzi, ikerketa honek izan baduela bere mugarik. Hasteko eta orain aipatu bezala, kasu azterketa bat den aldetik ezin dira ikerketaren emaitzok orokortu.

Datuak ikastola batera mugatuak daudenez adierazgarriak dira ikastola horretarako soilik eta ezin orokortu daitezke beste ikastoletara.

\section{IKERKETA EMAITZA}

\section{Metodologia eta ikasketa prozesua EKI proiektuaren azterketan ikasgaien arabera. (@Ikasketa_prozesua)}

EKI proiektuak ikasketa prozesuari irizten diona kontuan izanda, ikasleak gai izan behar du egoera problematikoei aurre egiteko baliabideak bere kabuz bilatzeko, edukiak ariketa eta jardueren bitartez eskuratzen dituen bitartean. Horretarako, unitate didaktikoak arazo-egoera batean izaten du abiapuntua eta simulazioak eta animazioak erabiltzen dira maiz. Hortaz, faktore ugari dituen fenomeno honek metodologia deituriko aldagaiaren bitartez aztertzea du helburu.

Honako taula hauetan, ikasketa prozesuaren (integrazioaren pedagogiaren) dimentsioaren batezbestekoa ageri da ikasgaika.

4. taula

\section{Ikasketa prozesua dimentsioaren batezbestekoak}

\begin{tabular}{l|c|c|c}
\hline \multicolumn{4}{c}{ Deskribatzaileak } \\
@Ikasketa_prozesua & $\mathrm{N}$ & bb & Desbiderapen estandarra \\
\hline Euskara & 12 & 16,6667 & 3,67630 \\
Natur zientziak & 18 & 13,1111 & 4,49691 \\
Gizarte/SSLIC & 21 & 16,7619 & 2,98169 \\
Ingelesa & 19 & 16,4211 & 3,54833 \\
Lengua castellana y literatura & 20 & 17,6500 & 2,60111 \\
Matematika & 18 & 11,2222 & 4,06644 \\
Totala & $\mathbf{1 0 8}$ & $\mathbf{1 5 , 3 2 4 1}$ & $\mathbf{4 , 2 0 6 8 7}$ \\
\hline
\end{tabular}


Ikasketa-prozesua aldagaiaren batezbestekoa 15.3koa da (4. taula). Halere, zientzien blokean (Fisika-Kimika eta Matematika) batezbestekoak behera egiten du 11.22 eta 13.11 ko batezbestekoekin. Hizkuntzetan eta Gizarte Zientzietan aldiz, lortzen dira batezbesteko altuenak, 16.66, 16.42, 17.65 eta 16.65 eko batezbestekoekin ikus daitekeen moduan (4. taula). Hortaz, fenomenoaren ezaugarriak maiztasun handiagoz izaten dira hizkuntzen blokean zientzien blokean baino batezbestekoen taulak (4. taula) adierazten duen moduan.

5. taula

Ikasketa prozesua dimentsioaren ANOVA analisia

\begin{tabular}{l|c|c|c|c}
\hline \multicolumn{5}{|c}{ ANOVA } \\
@Ikasketa_prozesua & gl & F & Sig. & Eta karratua \\
\hline & 5 & 9,167 &, 000 &, 310 \\
\hline Entre grupos & 102 & & & \\
Dentro de grupos & $\mathbf{1 0 7}$ & & & \\
Totala & & & & \\
\hline
\end{tabular}

Ikasketa-prozesuaren eta ikasgaien, bi aldagaien, arteko erlazioa esanguratsua da oso (5. taula, $\mathrm{p}=0.000$ ). Esangura mailak adierazten $\mathrm{du}, \mathrm{bi}$ aldagaien arteko erlazioa probabilitatetik kanpo esanguratsua ote den, zehaztu gabe erlazioa edo diferentzia hori sendoa ala txikia den. Datu hori ikusteko, efektuaren tamaina neurtzen duen datuan, Eta karratuan, $\eta 2$, erreparatu behar dugu (5. taula).

Beraz, ikasketa prozesua eta ikasgaiak alderatuta esan daiteke egon badagoela kasualitatez ematen ez den loturarik eta lotura hau nabarmena edo sendoa dela Eta-karratuak $\eta 2=0.310$ koefizientea ematen baitu.

Azkenik, ikasleen ikuspuntutik aztertuta ikasgaien arteko eta ikasketa prozesuaren erlazioari erreparatzen badiogu, erlazio esanguratsua orokorrean gertatzen dela esan daiteke, berriro ere, Hizkuntzen eta Gizarte Zientzien blokeen eta beste zientzien (Fisika-Kimika eta Matematika) blokeen artean (6. taula Tukey analisian).

Oso azalekoa da, adibidez, Matematikak duen esangura maila Gizarte, Ingelesa eta Gaztelerarekin alderatuz $p=0.000$ baita, berriz ere Zientzia eta Hizkuntzen blokeen arteko ezberdintasunak azaleratuz. 
EKI hezkuntza proiektu berritzailea eta bere ikasgaikako...

6. taula

\section{Ikasketa prozesua dimentsioan Tukey analisia}

\begin{tabular}{|c|c|c|c|c|c|}
\hline \multicolumn{6}{|c|}{ Alderaketa anitzak } \\
\hline \multicolumn{6}{|c|}{ Aldagaia: @Ikasketa_prozesua } \\
\hline & $\begin{array}{c}\text { (I) } \\
\text { 1.Ikasgaiak }\end{array}$ & $\begin{array}{c}(\mathrm{J}) \\
\text { 1. Ikasgaiak }\end{array}$ & $\begin{array}{l}\text { Bb diferentziak } \\
\text { (I-J) }\end{array}$ & $\begin{array}{c}\text { Errore } \\
\text { estandarra }\end{array}$ & Sig. \\
\hline \multirow{17}{*}{$\begin{array}{l}\text { HSD } \\
\text { Tukey }\end{array}$} & \multirow{2}{*}{ Euskara } & Natur zientziak & 3,55556 & 1,33382 & 091 \\
\hline & & Matematika & $5,44444^{*}$ & 1,33382 & 001 \\
\hline & \multirow{3}{*}{$\begin{array}{l}\text { Natur } \\
\text { zientziak }\end{array}$} & Euskara & $-3,55556$ & 1,33382 & 091 \\
\hline & & Gizarte/SSLIC & $-3,65079^{*}$ & 1,14961 & ,024 \\
\hline & & Lengua castellana & $-4,53889^{*}$ & 1,16279 & 002 \\
\hline & \multirow{3}{*}{$\begin{array}{l}\text { Gizarte/ } \\
\text { SSLIC }\end{array}$} & Euskara & 09524 & 1,29515 & 1,000 \\
\hline & & Natur zientziak & $3,65079^{*}$ & 1,14961 & 024 \\
\hline & & Matematika & $5,53968^{*}$ & 1,14961 & 000 \\
\hline & \multirow{2}{*}{ Ingelesa } & Euskara &,- 24561 & 1,31970 & 1,000 \\
\hline & & Matematika & $5,19883^{*}$ & 1,17720 & 000 \\
\hline & \multirow{3}{*}{$\begin{array}{l}\text { Lengua } \\
\text { castellana y } \\
\text { literatura }\end{array}$} & Euskara & ,98333 & 1,30687 & ,975 \\
\hline & & Natur zientziak & $4,53889^{*}$ & 1,16279 & 002 \\
\hline & & Matematika & $6,42778^{*}$ & 1,16279 & 000 \\
\hline & \multirow{4}{*}{ Matematika } & Euskara & $-5,44444^{*}$ & 1,33382 & 001 \\
\hline & & Gizarte/SSLIC & $-5,53968^{*}$ & 1,14961 & 000 \\
\hline & & Ingelesa & $-5,19883^{*}$ & 1,17720 & 000 \\
\hline & & Lengua castellana & $-6,42778^{*}$ & 1,16279 & 000 \\
\hline
\end{tabular}

Bestalde, irakaslariarengan alegia, metodologiak izan badu zeresanik, izan ere, EKIren metodologiak irakaslearen beraren eskola-emate tradizionala birdefinitzera eraman baitu, irakasleen eztabaida-taldean islatu bezala:

$08^{\prime}: 15^{\prime \prime}$

NT: Era berean ere, gure rola, irakaslearen rola ere, horren inguruan hausnartzera bultzatzen gaitu ez? Ze ni igual egon ninteke nire «txapa» 
botatzen baina nahi ez nahi proposamenak batzuetan behartzen zaitu aldamenean, atzean jartzen...orduan horren inguruan hausnarketa ekarri digu mintegian ere bai.

Eztabaida taldekideek, aitzitik, EKI proiektuari ikasleak protagonistak izan daitezen saiakera aitortzen diote, eta baita horren inguruan hausnartzera bultzatzea ere.

\section{EKI proiektuaren erabileraren azterketa ikasgaien arabera. (@EKI_Klasean)}

Honako taula hauetan, erabilera dimentsioaren batezbestekoa ageri da ikasgaika.

\section{7. taula}

\section{EKI erabilera dimentsioaren batezbestekoak}

\begin{tabular}{|c|c|c|c|}
\hline \multicolumn{4}{|c|}{ Deskribatzaileak } \\
\hline & $\mathrm{N}$ & $\mathrm{bb}$ & Desbiderapen estandarra \\
\hline Euskara & 12 & 18,6667 & 2,70801 \\
\hline $\begin{array}{l}\text { Fisika-kimika/Biologia-Geologia } \\
\text { (natur zientziak) }\end{array}$ & 18 & 14,3333 & 5,20181 \\
\hline Gizarte/SSLIC & 21 & 9,7143 & 3,71676 \\
\hline Ingelesa & 19 & 15,0000 & 2,30940 \\
\hline Lengua castellana y literatura & 20 & 17,4000 & 1,90291 \\
\hline Matematika & 18 & 7,2778 & 2,96659 \\
\hline Totala & 108 & 13,4259 & 5,12316 \\
\hline
\end{tabular}

EKIren erabilerak ikasgaika du interesa. Hortaz, esan daiteke, Gizarte eta Matematikan gutxi erabiltzen dela EKI digitala. Kasu honetan ere, erabilerarik altuena 3 hizkuntzetan gertatzen da, Ingelesa, Euskara eta Gaztelanian (7. taula). Fisika-Kimikan EKI digitala erabileran eskala erditik pasatzen dutenen artean baxuena da. Oraingo honetan Gizarte Zientziek, zientzien blokearekin egiten dute bat, erabilerari dagokionez, bederen 9,71eko batezbestekoa lortu baitu, (7. taula). 
8. taula

EKI erabilera dimentsioaren ANOVA analisia

\begin{tabular}{l|r|c|c|c}
\hline \multicolumn{1}{|c}{ ANOVA } \\
@10.EKI_klasean \\
\hline & gl & F & Sig. & Eta karratua \\
\hline Entre grupos & 5 & 30,239 &, 000 &, 597 \\
\hline Dentro de grupos & 102 & & & \\
\hline Totala & $\mathbf{1 0 7}$ & & & \\
\hline
\end{tabular}

Bestalde, bi aldagaien arteko lotura oso sendoa eta adierazgarria dela balioesten ahal da (10. taula, $\mathrm{p}=0.000$ eta Eta-karratua: 0.597).

Azkenik, ikasgaien arteko ezberdintasunari erreparatzen badiogu, orokorrean, erlazio esanguratsua egon badago, Gizarte eta Matematika eta beste ikasgai guztien artean (9. taulan). Bi ikasgai hauetan, hain zuzen ere, EKI ikasmaterialaren erabilera baxuena azaleratzen baita.

Aldi berean, eztabaidan parte hartutako irakasleek bat egiten dute nolabait ikasleek iritzi orokorrarekin, izan ere, egokitzat jotzen baitute EKIren erabilera, bereziki hizkuntzen arloan:

Eztabaida 10':33',

HZ: Hizkuntzei dagokionez... Ostadarrekin DBHn jauzia oso handia ez da izan. Gu behintzat ostadarrekin gustura gaudenez, nahiko naturalki edo eman dugu salto hori. Egia da, Ostadar erabiltzen genuela Euskaran eta Gazten, ordea Ingelesean ezetz esanen nuke, ...orduan, klaro, orain ere EKIrekiko pertzepzioa ere ezberdina da.

$11^{\prime}: 09^{\prime \prime}$

HZ: ...Hitz egiten dugunean hizkuntzei buruz Gazte eta Euskarakoak ados gaude eta ordea, ingeleskoak hor daude beraien gorabeherekin. Orduan hori da ere beste erronka bat duguna.

Esanguratsua da, beraz, Ingelesaren kasuan emaitzok behera egitea. Horren atzean azken hamarkadan dagoeneko Gaztelania eta Euskara ikasgaietan Ostadar materiala erabili izana egon daiteke, erabilera orokorrean eta ariketa ereduetan zein testugintzan nolabaiteko eskarmentua ekarri baitie irakasle hauei partikularki. 


\section{9. taula}

\section{EKI erabilera dimentsioaren Tukey analisia}

\begin{tabular}{|c|c|c|c|c|c|}
\hline & & Alderaketa anitz & & & \\
\hline Aldagai & @EKI_klasean & & & & \\
\hline & $\begin{array}{c}\text { (I) } \\
\text { 1. Ikasgaiak }\end{array}$ & $\begin{array}{c}\text { (J) } \\
\text { 1. Ikasgaiak }\end{array}$ & $\begin{array}{c}\text { Bb diferentziak } \\
\text { (I-J) }\end{array}$ & $\begin{array}{c}\text { Errore } \\
\text { estandarra }\end{array}$ & Sig. \\
\hline HSD & & Natur zientziak & $4,33333^{*}$ & 1,24118 & ,009 \\
\hline & & Gizarte/SSLIC & $8,95238^{*}$ & 1,20520 & ,000 \\
\hline & Euskala & Ingelesa & $3,66667^{*}$ & 1,22805 & 040 \\
\hline & & Matematika & $11,38889^{*}$ & 1,24118 &, 000 \\
\hline & Fisika-kimika/ & Euskara & $-4,33333^{*}$ & 1,24118 & ,009 \\
\hline & Biologia- & Gizarte/SSLIC & $4,61905^{*}$ & 1,06976 & 001 \\
\hline & (natur zientziak) & Matematika & $7,05556^{*}$ & 1,11015 & 000 \\
\hline & & Euskara & $-8,95238^{*}$ & 1,20520 &, 000 \\
\hline & & Natur zientziak & $-4,61905^{*}$ & 1,06976 &, 001 \\
\hline & & Ingelesa & $-5,28571^{*}$ & 1,05450 & ,000 \\
\hline & & Lengua castellana & $-7,68571^{*}$ & 1,04056 &, 000 \\
\hline & & Euskara & $-3,66667^{*}$ & 1,22805 & ,040 \\
\hline & & Natur zientziak & 66667 & 1,09544 & ,990 \\
\hline & ingeresa & Gizarte/SSLIC & $5,28571^{*}$ & 1,05450 & ,000 \\
\hline & & Matematika & $7,72222^{*}$ & 1,09544 &, 000 \\
\hline & & Euskara & $-1,26667$ & 1,21610 & ,903 \\
\hline & Lengua castellana & Gizarte/SSLIC & $7,68571^{*}$ & 1,04056 &, 000 \\
\hline & & Matematika & $10,12222^{*}$ & 1,08204 &, 000 \\
\hline & & Euskara & $-11,38889^{*}$ & 1,24118 &, 000 \\
\hline & & Natur zientziak & $-7,05556^{*}$ & 1,11015 &, 000 \\
\hline & vratematıка & Ingelesa & $-7,72222^{*}$ & 1,09544 & 000 \\
\hline & & Lengua castellana & $-10,12222^{*}$ & 1,08204 &, 000 \\
\hline
\end{tabular}


Bestalde, EKI proiektuari leporatu diote ikasgaika edo diziplinako materiala garatzerako orduan, alderdi komertzialaren gailentzea. Natur Zientziaren irakaslearen aburuz, konpetentzietan oinarritutako materiala benetakoa balitz, arloka izan beharrean, diziplinaka garatu beharreko materiala izan beharko litzateke. Gainera, arloka diseinatua egoteak, bai irakasle eta bai ikasleentzat, suposatzen duen gainkarga ere desabantaila da: "Arloka diseinatua egotearen zera bat da, gainkarga bat, horrelako ariketetan (IKT jardueretan), ikasleen azterketetan eta gainkarga bat ere irakaslearen lanean.» (NT, $\left.33^{\prime}: 53^{\prime \prime}\right)$.

\section{EKI proiektuaren asebetetzearen azterketa ikasgaika}

Likert eskaladun hiru galderotan aipatutako itemak 1 eta 5 artekoak ziren, 1, oso gaizkiren sinonimo; eta 5, bikainarena.

Goraipatzekoa da erditik beherako batezbestekoak EKIren asebetetze mailaren galderan agertzen direla, EKI gutxien erabiltzen duten ikasgaietan, hain zuzen ere. Bestalde, ikasleen iritzia kontuan hartuz, Gaztelania da puntuaziorik onena atera duen ikasgaia, neurtu diren 3 maila ezberdinetan 3 tik goragoko batezbestekoa lortu baitu. Ezberdintasunak ez dira zoriz gertatu esangura maila $p=0.001, p=0.011$ eta $p=0.046$ baitira hurrenez hurren.

Esangura mailari eta lotura honen indarrari dagokienez, 3 galderek ikasgaien aldagai kategorikoarekin erlazio esanguratsua azalean uzten dutela aipatu beharra dago. Eta-karratuaren koefizientean erreparatuz berriz, «Nola sentitzen zara ebaluazioarekin» galderaren erlazioa izango litzateke soilik lotura sendoa edo indarra duena (0.191).

«Zerbait aldatuko zenuke? baiezkoa bada azaldu labur» Galdera hau izan da inkesta osoan galdera ireki bakarra zeinaren erantzunean ikasleek bere iritzia sakon, zabal eta ñabardurarik gehitzeko moduan adierazteko aukera izan duten.

Galdera ireki honek ikasleriaren iritzia sakontasun handiz ezagutzeko balio du. Oso esanguratsua gerta dakiguke gehien errepikatzen den ideia: ordenagailua kendu. Galdera irekia 97 ikaslek erantzun dute 108tik, zeintzuetatik 48k ordenagailuaren erabileraren murrizketa edo ordenagailuaren desagertzea eskatzen duten $(\% 49,48)$. Ideia honen atzean azalpen ezberdinak agertu dira; distraitzen direla, batxilergoa eta azterketak ez dituztela ordenagailuen bidez egiten, beraz, ez dietela zentzurik ikusten, sarea eroriz gero denbora galera, ortografia eskuz lantzerako orduan zailtasunak... Agertu diren beste ideia batzuk honako hauek izan dira: talde lanean gehiagotan aritzea, webguneen blokea kentzea, ...

Aldi berean ordenagailuaren distrakzio ahalmen handia aipatzen dute, izan ere chromebook-ak, erabili beharreko Ekiguneaz gain, sarearen oparotasun guztia eskaintzen baitu. Ikasleek tentazio hitza erabili dute, txatak, on-line jolasak, youtube... eta bestelakoen tentagarritasuna salatuz. 
10. taula

Ikasleen asebetetzearen batezbestekoa ikasgaika

\begin{tabular}{|c|c|c|c|c|}
\hline \multicolumn{5}{|c|}{ Txostena } \\
\hline \multicolumn{2}{|c|}{ 1. Ikasgaiak } & \multirow{2}{*}{$\begin{array}{c}\begin{array}{c}\text { Nola } \\
\text { sentitzen zara } \\
\text { ebaluazioarekin? }\end{array} \\
3,08\end{array}$} & \multirow{2}{*}{$\begin{array}{c}\text { Nola } \\
\begin{array}{c}\text { sentitzen zara } \\
\text { EKIrekin lan } \\
\text { egiten? }\end{array} \\
2,75\end{array}$} & \multirow{2}{*}{ 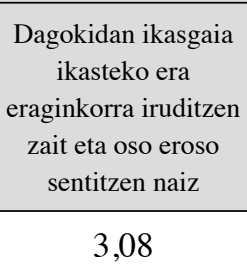 } \\
\hline \multirow{3}{*}{ Euskara } & Batezbestekoa & & & \\
\hline & $\mathrm{N}$ & 12 & 12 & 12 \\
\hline & Desbiderapen estandarra & 1,084 & 1,357 & 1,084 \\
\hline \multirow{3}{*}{$\begin{array}{l}\text { Fisika-kimika/ } \\
\text { Biologia- } \\
\text { Geologia (natur } \\
\text { zientziak) }\end{array}$} & Batezbestekoa & 2,78 & 2,33 & 2,22 \\
\hline & $\mathrm{N}$ & 18 & 18 & 18 \\
\hline & Desbiderapen estandarra & ,943 & ,970 & 1,114 \\
\hline \multirow{3}{*}{ Gizarte/SSLIC } & Batezbestekoa & 3,67 & 2,24 & 3,05 \\
\hline & $\mathrm{N}$ & 21 & 21 & 21 \\
\hline & Desbiderapen estandarra & ,966 & 1,221 & 1,431 \\
\hline \multirow{3}{*}{ Ingelesa } & Batezbestekoa & 2,53 & 3,16 & 2,63 \\
\hline & $\mathrm{N}$ & 19 & 19 & 19 \\
\hline & Desbiderapen estandarra & 1,124 & ,834 & 1,065 \\
\hline \multirow{3}{*}{$\begin{array}{l}\text { Lengua } \\
\text { castellana y } \\
\text { literatura }\end{array}$} & Batezbestekoa & 3,60 & 3,10 & 3,40 \\
\hline & $\mathrm{N}$ & 20 & 20 & 20 \\
\hline & Desbiderapen estandarra & ,598 & 912 &, 821 \\
\hline \multirow{3}{*}{ Matematika } & Batezbestekoa & 3,39 & 2,33 & 2,67 \\
\hline & $\mathrm{N}$ & 18 & 18 & 18 \\
\hline & Desbiderapen estandarra & ,778 &, 767 & 1,372 \\
\hline \multirow{3}{*}{ Total } & Batezbestekoa & 3,19 & 2,65 & 2,84 \\
\hline & $\mathbf{N}$ & 108 & 108 & 108 \\
\hline & Desbiderapen estandarra & 1,000 & 1,062 & 1,209 \\
\hline
\end{tabular}


Aitortzen dutenarengatik gehiengoak ibiltzen du papera. Ikasterakoan apunteak, eskemak, laburpenak... tankera klasikoagokoak eta eskuz idatzizkoak finean, teoria landu ahal izateko egiten dituzte, ordenagailutik bertatik ikasteko zailtasuna azaleratzen delarik.

Ildo praktikoago batetik inoizka wifia erortzen dela salatzen dute, berau gabe ezin baita inolako lanik egin, ordenagailu mota honek ez baitu sikiera programa minimorik bertan lanean aritzeko edota memoria askirik aplikazioak bertan instalatzeko.

Eztabaida taldean parte hartutako hiru irakasleek adostasuna adierazi zuten EKIren onurarik garrantzitsuena hizkuntza amankomuna sortzean zetzala: «EKIk gutxienez jarri gaitu hizkuntza amankomunean» (NT, 6':50' '). Proiektuaren mugak ikusita ere, hortik aurrera berariazko beharrei erantzuna emateko eta proiektu propioa eraikitzeko oinarria dela uste dute.

Dena den, maila desberdinak ageri dira irakasleriaren solas-taldean asebetetzeari dagokionez. Batetik, gaztelania eta euskara-irakasleak erabat identifikatzen dira EKIrekin, haien esanetan hizkuntzak eta ulermena proiektuaren indar-gune baitira, Ostadar proiektuak irekitako ildoari jarraikiz. Natur eta Gizarte Zientzietan hainbat ñabardura jartzen dituzte mahai gainean, ordea:

\section{Eztabaida 12':22',}

NT: Beste ikastoletan ere ateratzen da, zientzia proiektua ez da hizkuntza proiektua bezain sendoa. Zientziatzat hartzen ditut Gizarte Zientziak eta Naturaren Zientziak. Orokorrean, iruditzen zait, egin den lana hizkuntzetan Ostadarretik eta, baduela zera sendoa eta zientzia proiektua ez da hain sendoa.

Baina aldi berean Natur zientzien kasuan eroso sentitzen dira ikasgaia EKIren bitartez lantzen, nahiz eta onartzen duten ibilbide luzea gelditzen zaiela hizkuntzek dituzten emaitzak erdiesteko. Aldiz, ikasleen iritziari erreparatzen badiogu ikusten da nola Natur zientzia ikasgaian asebetetze galderan $2.33 \mathrm{ko}$ batezbestekoa lortzen duten (10. taula) erditik beherakoa.

Gizarte zientzietan lortutako emaitzak, aldiz, aurreko bi blokeen erdibidean egonen lirateke. Hainbat alderditan hizkuntzekin bat egiten du eta beste batzuetan, berriz, erabileran zehazki, Matematikarekin.

\section{Eztabaida 20':40',}

GZ: ...Humanitateak nola jorratzen zituen, bai EKIk eta bai Ostadarrek, iruditzen zait akats hori arrastaka duela. Horren atzean dago Humanitateek galdu duten presentzia bat. LOMCEk ere ez digu inongo mesederik egiten.

$21^{\prime}: 46^{\prime \prime}$

GZ: Humanitateetan zer da jakintza? Gizartean, eta EKI honen isla da, ez da EKIren errua, desagertzen ari da konpetentzia kultural dei dezakedan bat. 


\section{ONDORIOAK ETA EZTABAIDA}

Agian goizegi da EKIren zabalera eta sakontasuna dituen proiektua balioesteko; izan ere, bost urteko ibilbide laburra baino ez du egin eskutan duzun artikulu hau egin denean. Esan nahi baita, EKIren onurak, aurreko proiektuen aldean eta eskolak emateko tankeren ondoan izan ditzakeen abantailak oraindik ezin izango direla bere osotasunean hauteman, are gehiago, ziur aski EKI ez da behar bezala iritsi zirrikitu guztietara, eta modu berean urteen poderioz igarriko zaizkio izan ditzakeen hutsuneok.

Hezkuntzaren mundua eta hango eragileen mintzoak hartu dira kontuan ikerketa osatzeko, ondorioz, ikasgaion mugaren alde bietan gailendu dira oso antzerako ideiak eta iritziak, zeinetan berebiziko korrespondentzia agertu baita gure arreta ikasgaika jarri dugunean, kasualitateari ezer gutxi zor zaion seinale.

Garai bateko hezkuntzan irakasle bakoitza bere ikasgaian maisu baino, jabe eta jauntxo zen. Gaur egun ere, horren ondoriotasuna mantentzeko joera dago

Derrigorrezko Bigarren Hezkuntzan oraindik ikasgai bakoitza bere izaera propioa eta erreinua mantentzeko joera dagoela esan dezakegu, eta beste ikasgaiekiko inolako interkonexiorik sortzen ez dela. Honela, materia eta berau aurkezteko tenorean subirano sentitu baita, bai eta ebaluazio ereduan ere. EKIk hizkuntza eta hezkuntzaren berariazko hiztegia erabiltzen derrigortu ditu, bi azterketa mota planteatzeraino: edukiak eta konpetentziak, banaketa klasikoaren arabera eta garai bateko teoria eta praktikaren arteko ezberdintze zaharkituaz haratago. Ikasleria izan da horren onuraren hartzaile zuzena.

\section{EKI proiektuaren integrazio pedagogikoa ez da irakasgai guztietan maila berdinean gauzatzen}

EKIk inplementazio gorabeheratsua du irakasgaien arabera. Euskara eta Gaztelania dira EKIk aldarrikatzen duen metodologia gehien betetzen duten eta EKI digital ikasmateriala gehien erabiltzen duten ikasgaiak, eta bat datoz ikasleak nahiz irakasleak. Ikasgai hauetan agertzen dira batezbestekorik altuenak analisietan. Hori gertatzearen arrazoietako bat izan daiteke, irakasleen talde-eztabaidan hala agertu den bezala, ikasgaiak EKI aurretik Ostadarrekin (konpetentzietan oinarritutako ikasmateriala) izandako ibilbidea. Honi gaineratu diezaiokegu zentro honetako hizkuntza-irakasleak Ostadar ekimenean trebatuak izan direla azken hamarkadan, nolabaiteko abantaila hartu dutelarik, horrenbesterekin. 
EKI hezkuntza proiektu berritzailea eta bere ikasgaikako...

\section{EKIren erabilerak hizkuntzetan du bere adierazgarririk onena}

Bestalde, argi dago EKIk ez diela ikasgai guztien beharrei erantzun ekitatezkoa eskaintzen. Datuak eskutan, agerikoa da Natur zientzien eta Matematikako irakasgaien proiektuak ez duela Hizkuntzetakoak erakusten duen sendotasuna. Horren ondorioz, ikasgai horien kudeaketa okertzat jo dute bai irakasleek eta bai ikasleek ere. Horrek ez du esan nahi Natur zientzietan eta Matematikan EKI programaren bidez konpetentziak lortzen laguntzen ez duenik, Amezuak (2014) egindako ikerketan aipatzen den moduan konpetentziak hobeto lantzen laguntzen dute metodologia tradizionalekin baino.

EKI proiektuaren asebetetze maila altua da, batez ere, gehien erabiltzen eta integratuta dauden ikasgaietan

EKIk berrikuntzarako oinarria ezarri du. Lerro-buruak irudika dezakeen hasierako arrakastaren gibelean, berrikuntza oinarri hori oso oinarrizkoa da oraindik. Izan ere, betiko sei irakasgai klasikoak hartzen baititu, lehen eta bigarren mailako ikasgaiak ezartzeraino.

Collek (2007) aipatzen zuen bezalaxe, hezkuntzan ere berrikuntza asko indar handiz ezartzen dira, modak bailiran, baina hasierako koloretako txinpartak azkar ahazten dira, eta ikasturtetik ikasturtera distira galtzen dute. Ikergaitzat hartu dugun zentroan, itxura denez, badirudi EKI geratzeko etorri dela; hala igarri da bederen, elkarrizketatuko irakasleen esanetan.

Behin betiko EKIren alde egin dezan, irakasleriak nahiko luke, EKIren beraren etengabeko egokitzeaz eta fintzeaz gain, denboran ere irautea. Irakasleriaren baitan aho bateko adostasuna azaldu zen EKIk hezkuntzaren hainbat alderdi garrantzitsuren inguruan (irakaslearen rola, digitalizazioa, metodologia...) hausnartzeko hizkuntza amankomuna sortu izanaren ideian.

Beraz, ideia hau ardatz hartuz, oinarri sendorik egon badago EKItik abiatuta ikastolak behar duen proiektu propioa eraikitzeko, ikastola konkretu honen beharretara egokituz. Hala eta guztiz ere, proiektu berri guztiekin egin beharko litzatekeen moduan, ezinbestekoa izan beharko litzateke inplementatutako egitasmoaren kontrola, jarraipena eta ebaluazio kritikoa ahalbidetzen duten tresnak aurreikustea etorkizunari begira. Finean, etengabeko hobekuntza prozesuan egon behar baitu hezkuntzak, edozein gizarte esparruk bezalatsu.

EKI paper liburuko eta EKI modu digitalaren arteko eztabaida gainditzeko beharra hautematen da

Ezin betirako definituta utzi non akitzen den edozein ikerketaren konkrezio edo sakontasun maila. Honetan bertan ere hainbat ate ireki geratzen dira. Batetik EKIk apustu zehatza egin du digitalizazio eta IKTen alde, Ge- 
rekak, Odriozolak, Arregik eta Verak, (2017) egindako lanean «Eki Proiektutik eki digitalera: ikaskuntza esperientzia berritzailea», argi islatzen da zein bidetatik eraman nahi den proiektua, baina ikasleriaren migrazio digitalaren bizipena eta irakasleen iritzia ez dira kasu honetan espero bezain onak izan. Digitalizazioarekin ezer berritzen ez bada edo urtetik urtera, gauza bera egiten bada, eragileek pentsatuko dute onurarik ez dakarrela.. Bestalde, etengabeko migrazio edo aldaketa batean sartuz gero, eredu bat sendotzeko aukerarik ez dagoela pentsatuko dute. Nola gainditu eztabaida?

Bukatzeko eta hausnarketa gisa esan daiteke ohiko talde-lana, ikasleriak lantalde kooperatiboen ereduari jarraikiz egin ditzan bilatzen duela EKIk asmorik txalogarrienarekin. Zenbaterainokoa da honen guztiaren lorpen maila? Ikasle profil guztiek parte hartzen al dute berorretan?Ate asko dira zabalik oraindik ere.

\section{ERREFERENTZIAK}

Altuna, J. (2010). Integración de internet en la didáctica de la asignatura Conocimiento del medio» en el tercer ciclo de primaria (Doctoral dissertation, Universidad del País Vasco-Euskal Herriko Unibertsitatea) Euskal Herriko Unibertsitatearen Argitalpen Zerbitzua, Donostia.

Amezua, N. (2014). Evaluación de la adquisición de competencias mediante el proyecto EKI en $2 .^{\circ}$ de la ESO para la materia de ciencias de la naturaleza. Euskar Herriko Unibertsitatea (UPV-EHU).

Bujan, K. (2001). Kasu azterketa metodoaren izaera: kasu azterketa diseinua EHUko hainbat tesi lanetan. Revista de psicodidáctica, 11-12, 133-142.

Cepeda J. M. (2004). Metodología de la enseñanza basada en competencias. Revista Iberoamericana de Educación, 35(1), 1-10

Coll, C. (2007). Las competencias en la educación escolar; algo más que una moda y mucho menos que un remedio. Aula de innovación educativa, 161, 34-39.

Dendaluze, I. (2008). Metodologías de la investigación en Ciencias Sociales: diez palabras clave. En F. Etxeberria, L. Sarasola, J. F. Lukas, J. Etxeberria eta A. Martxueta, (Coords.), Convivencia, equidad, calidad (211-253). San Sebastián: Erein.

Esteve, J. M. (2003). La tercera revolución educativa. La educación en la sociedad del conocimiento. Barcelona: Paidós Ibérica

Fernández Enguita, M. (2001). Educar en tiempos inciertos. Madrid: Ediciones Morata.

Gil, P. (2013). Hezkuntzaren psikologia: teoria eta praktika. Euskara eta eleaniztasuneko errektoreordetzaren sare argitalpena. Donostia: Euskal Herriko Unibertsitatearen Argitalpen Zerbitzua.

Gereka, J., Odriozola, O., Arregi, A. eta Vera, P. (2017). Eki proiektutik eki digitalera: ikaskuntza esperientzia berritzailea. En I. Maiz, U. Garay, C. Castaño (Eds.), Nuevas tecnologías y tendencias en la Educación / Teknologia berriak eta Hezkuntza joerak. (433-456). Bilbao: Universidad del País Vasco / Euskal Herriko Unibertsitatea, Argitalpen Zerbitzua. 
EKI hezkuntza proiektu berritzailea eta bere ikasgaikako...

Gimeno Sacristán, J. G. (2008). Educar por competencias, ¿qué hay de nuevo?. Madrid: Ediciones Morata.

Ikaselkar (2014). EKI Proiektua. Donostia: Elkar Argitaletxea. Honako webgune honetatik berreskuratua: http://www.ikaselkar.eus/wp-content/themes/ikaselkarchild/eki_proiektua/pdf/eki-proiektua.pdf.

Juaristi, P. (2003). Gizarte ikerketarako teknikak. Teoria eta adibideak. Donostia: Euskal Herriko Unibertsitatearen Argitalpen Zerbitzua.

Lizarralde, J. (2016). EKI proiektuko Euskararen lekukoak unitatea: testu-generoetan oinarritutako didaktika?. Euskar Herriko Unibertsitatea, Hizkuntzalaritza eta Euskal Ikasketak Saila (UPV-EHU).

Llorens, F. (2013). En pos de la educación activa. Madrid: Cátedra UNESCO de Gestión y Política Universitaria y Universidad Politécnica de Madrid.

Mergel, B. (1998). Diseño instruccional y teoría del aprendizaje. Honako webgune honetatik berreskuratua: https://etad.usask.ca/802papers/mergel/espanol.pdf

Norman, G. R., eta Streiner, D. L. (1996). Biostatistics: the bare essentials. Madrid: Mosby Doyma Libros.

Santana, M.S. (2007). Enseñanza y Aprendizaje. La enseñanza de las matemáticas y las Ntic. Una estrategia de formación permanente. (32-172). Tarragona: Universitat Rovira i Virgili.

Stake, R. E. (1998). Investigación con estudio de casos. Madrid: Ediciones Morata.

Siemens, G. (2004). Conectivismo: una teoría de aprendizaje para la era digital. Honako webgune honetatik berreskuratua: www.diegoleal.org/docs/2007/ Siemens(2004)-Conectivismo.doc

Yin, R.K. (2003). Case study Research. Design and Methods. (3. ${ }^{a}$ edición). Londres: SGAE publications.

Zabala, J. (2015). Ikasleari komunikatzeko behar dituen tresnak ematea dagokigu. Arlo ezberdinetatik, gainera. BAT Soziolinguistika Aldizkaria 96(3), 129-138. 